\title{
ZÁVISLOST NÍZKOTEPLOTNÍCH VLASTNOSTÍ ASFALTOVÝCH SMĚSÍ NA VLASTNOSTECH POJIVA
}

\author{
DEPENDENCY OF ASPHALT MIXTURES LOW TEMPERATURE \\ PROPERTIES ON BINDER PROPERTIES
}

\author{
Petr Veselý, ${ }^{*}$
}

"Petr.Vesely5@vut.cz

${ }^{1}$ Vysoké Učení Technické v Brně, Fakulta stavební, Veveří 331/95, 60200 Brno

\begin{abstract}
Abstrakt
Práce se zabývá korelací výsledků nízkoteplotních zkoušek asfaltových směsí s výsledky nízkoteplotních zkoušek nejčastěji používaných asfaltových pojiv. Vlastnosti použivaných materiálů v teplotách, které se s měnícím klimatem stále častěji přibližují kritickým hodnotám, jsou stále více aktuálním tématem, které nesmí být opomínáno. Snahou této práce je poukázat na míru v jaké je možné ovlivnit tyto vlastnosti pomocí různých pojiv. Pro tento účel byly provedeny zkoušky, kterými jsou mimo jiné určení kritické teploty zkouškou nízkoteplotních vlastností s rovnoměrným řízeným poklesem teploty (TSRST), kritického bodu lámavosti dle Fraase a průhybového trámečkového reometru.
\end{abstract}

\section{Klíčová slova}

Asfaltová směs, silniční asfalt, nízkoteplotní vlastnosti, TSRST, koeficient determinace

\begin{abstract}
The paper deals with results of tests for low temperature properties of asphalt mixtures in correlation with results of tests on low temperature properties of the bitumen used in those. Properties of materials used in temperatures, which with changing climate keep approaching the critical value, are still very current topic, which cannot be overlooked. The aim of this paper is to point out the extent in which we can affect these properties with different binders. For this purpose, low temperature tests were carried out which include the thermal stress restrained specimen test to set critical temperature of asphalt mixture, Fraasse breaking point and the bending beam rheometer.
\end{abstract}

\section{Key words}

Asphalt mixtures, bitumen, low temperature properties, TSRST, coefficient of determination 


\section{1 ÚVOD}

Cílem práce je specifikovat závislost výsledných vlastností použitých směsí na nízkoteplotních vlastnostech asfaltových pojiv. Asfalt je jedním ze základních typů pojiv používaných v silničním stavitelství, využívaném po celém světě pro svoje vlastnosti. Asfaltové pojivo se získává bud'to př́rodní cestou z tzv. asfaltových jezer nebo především destilací surové ropy a vyznačuje se různými vlastnostmi v závislosti na způsobu a místě zpracování. Asfalt se za vysokých teplot chová jako kapalina určená svou viskozitou a při nízkých teplotách se materiál chová elasticky a zvyšuje se jeho tuhost. Tato vlastnost snižuje schopnost asfaltu odolávat tahovému napětí při nízkých teplotách.

U asfaltů se určuje obor použitelnosti, což je vlastnost určující teplotní rozpětí mezi bodem měknutí a bodem lámavosti. Se změnou klimatu, která probíhá a do budoucna se neočekává zastavení tohoto trendu [1], se požadavek na velikost tohoto teplotního rozpětí zvyšuje. Pokud dojde ke špatnému návrhu směsi v souladu s jejími nízkoteplotními vlastnostmi, může docházet ke vzniku mrazových trhlin, které poskytují cestu protékající vodě z povrchu vozovky do jejího podloží. Se stoupající cenou ropy je snahou stavět vozovky s delší životností, nebot' cena rekonstrukce vysoce přesahuje cenu údržby těchto objektů [2].

Př́spěvek poskytuje stručný popis použitých metod a materiálu. Zároveň zohledňuje podobné relevantní práce provedené na podobné téma a diskutuje rozdíly v přístupu, jako je např́iklad použití různě modifikovaných asfaltů, kterým se praktická část této práce nevěnuje.

V práci jsou porovnány výsledky zkoušek asfaltových pojiv kritického bodu lámavosti dle metody Fraase a průhybového trámečkového reometru s výsledky zkoušky kritické teploty dle TSRST za použití asfaltů různých penetračních tř́́d. Mezi těmito výsledky byl určen koeficient determinace.

\section{POPIS SOUČASNÉHO STAVU}

Snaha o stavbu dlouhodobě udržitelných vozovek přispívá $\mathrm{k}$ tomu, aby byla tato problematika podrobně řešena. Měnící se klima je jedním z hlavních faktorů poškození silniční sítě, především silnic 2. a 3. tř́ídy, kterých je v České republice nejvyšší podíl [3]. Správný návrh vzhledem k teplotním změnám a kritickým zimním teplotám přináší nezanedbatelný ekonomický prŕnos pro Českou republiku vzhledem k nákladům vynaloženým na údržbu jejich komunikací.

Práce si dává za cíl seskupit data korelací výsledků, které poukazují na změnu vlastností směsí pouze se změnou pojiva, jelikož nízkoteplotní zkoušky asfaltových směsí se v širokém rozsahu neprovádějí.

\section{POUŽITÉ ZKUŠEBNÍ METODY}

K porovnání nízkoteplotních vlastností asfaltových pojiv a směsí vyrobených za použití těchto pojiv bylo zapotřebí provést zkoušky, jejichž postup provedení je popsán v následující části textu. Jedná se o nejčastěji používané zkoušky pro určení těchto vlastností, s výjimkou zkoušky v trámečkovém průhybovém reometru, která se standartně v praxi nepouživá, nebot' vyhodnocuje stejné vlastnosti jako zkouška bodu lámavosti dle Fraasse. Avšak zkouška v trámečkovém průhybovém reometru je moderní, mnohem přesnější metodou. Hlavním faktorem, proč se v praxi tato zkouška nepoužívá, je rozdíl v ceně př́slušenství k provedení těchto dvou zkoušek.

\section{Bod lámavosti dle Fraasse dle ČSN EN 12593}

Vzorek asfaltového pojiva o hmotnosti $(410 \pm 10) \mathrm{mg}$ se nahřátím samovolně rozprostře po odmaštěném ocelovém plišku o rozměrech $41,00 \times 20,00 \times 0,15 \mathrm{~mm}$. Teplota zahřívání by neměla překročit bod měknutí používaného pojiva o více jak $80^{\circ} \mathrm{C}$. Díky povrchovému napětí asfaltového pojiva by nemělo dojít k rozlití pojiva mimo ocelový plíšek. Po úspěšném rovnoměrném rozlití pojiva je potřeba vzorek nechat vychladnout na pokojovou teplotu. Takto připravený plišsek je vložen do př́stroje za zvýšené opatrnosti, aby nedošlo k žádnému narušení povrchu, které by mohlo ve finále vést ke vzniku trhliny a tím pádem ovlivnění výsledku zkoušky. Teplota uvnitř př́stroje klesá s rychlostí $1{ }^{\circ} \mathrm{C}$ za minutu. Při dosažení teploty o $10^{\circ} \mathrm{C}$ vyšší, než je očekávaný bod lámavosti, aplikujeme každou minutu s klesající teplotou také deformační napětí ohýbáním plíšku se vzorkem. Aplikování napětí na vzorek opakujeme každou minutu až do momentu, kdy dojde k porušení. Teplota, při které dojde k porušení vzorku je výsledkem zkoušky a je označována jako bod lámavosti [4]. 


\section{Modul tuhosti za ohybu dle ČSN EN 14771}

K vyhodnocení této zkoušky bylo využito průhybového trámečkového reometru. Tento reometr měří při zatěžování tříbodovým ohybem. Vzorky asfaltového pojiva se odlévají do forem definovaných normou ČSN EN 14771. Po vychladnutí pojiva dojde $\mathrm{k}$ seříznutí a odformování. Tím vznikne trámec asfaltového pojiva o rozměrech $6,4 \times 12,7 \times 127 \mathrm{~mm}$. Vzorek se temperuje hodinu v lihové lázni na testovací teplotě, která se u většiny používaných asfaltů pohybuje mezi $-10^{\circ} \mathrm{C}$ až $-40{ }^{\circ} \mathrm{C}$ odstupňovaná hodnotami po $6{ }^{\circ} \mathrm{C}$. Natemperovaný vzorek se vloží na podpory, aby jeho výška byla nejmenším rozměrem tělesa. Při zkoušce se na trámec nanáśí zatížení $980 \pm 50 \mathrm{mN}(100 \mathrm{~g})$ a poté se po dobu $240 \mathrm{~s}$ zaznamenává hodnota průhybu v závislosti na čase. Se známou hodnotou zatížení a hodnotou deformace lze určit modul tuhosti za ohybu Sm(t) v čase 60 s od počátku zatěžování. Druhým výsledným parametrem je tzv. m-hodnota, což je hodnota určující sklon křivky dotvarování v bodě $60 \mathrm{~s}$ na časové křivce [5].

\section{Zkouška TSRST dle ČSN EN 12697-46}

Jedná se o zkušební metodu používanou pro získání kritické teploty asfaltové směsi. Zkouška se provádí v nízkoteplotní komoře (Cyklon -40). Zkušební trámec o rozměrech $200 \times 50 \times 50 \mathrm{~mm}$ je pevně upnutý do př́istroje a postupným snižováním teploty dochází ke vzniku napětí z důvodu pevného upevnění a tím neumožnění jeho zkracování. V testovací komoře je uloženo "slepé" těleso, které má otvor pro teploměr, aby bylo možné měřit teplotu jak uvnitř komory, tak i v testovacím vzorku. Napětí se zvyšuje do té doby, dokud nedojde k porušení tělesa z důvodu vzniklé osové síly. Výsledkem této zkoušky je teplota, při které dojde k porušení vzorku trhlinou. Tato teplota se nazývá kritická teplota [6].

\section{POUŽITÉ MATERIÁLY}

V této práci bylo využito několika silničních asfaltů. Jedná se o ropné asfalty jednoho výrobce. Asfalty se liší hodnotou penetrace, která je rozděluje do několika tříd. V této práci byly použity následující třídy pojiv: 20/30, $35 / 50,50 / 70,70 / 100$ a $160 / 220$.

Asfaltová směs použitá v této práci je směs ACO 11+, která je nejrozšířenější směsí používanou pro obrusné vrstvy na českých komunikacích. Směs je vyrobena s vysokým podílem asfaltového pojiva, pro lepší názornost výsledků změny nízkoteplotních vlastností v závislosti na použitém pojivu. Kamenivo bylo odebráno $\mathrm{z}$ kamenolomu Luleč s výjimkou vápencové moučky, která pochází z Mokré. Nejdůležitějším faktorem pro asfaltovou směs je zastoupení jednotlivých frakcí (viz Tab. 1), její čára zrnitosti (viz Obr. 1) a mezerovitost, která činí 3,69\%.

Tab. 1 Zrnitost.

\begin{tabular}{cc}
\hline Síto [mm] & Propad [\%] \\
\hline 16 & 100,0 \\
11 & 93,8 \\
8 & 80,2 \\
4 & 53,9 \\
2 & 38,4 \\
1 & 28,1 \\
0,5 & 21,1 \\
0,25 & 14,4 \\
0,125 & 9,2 \\
0,063 & 7,0 \\
\hline
\end{tabular}

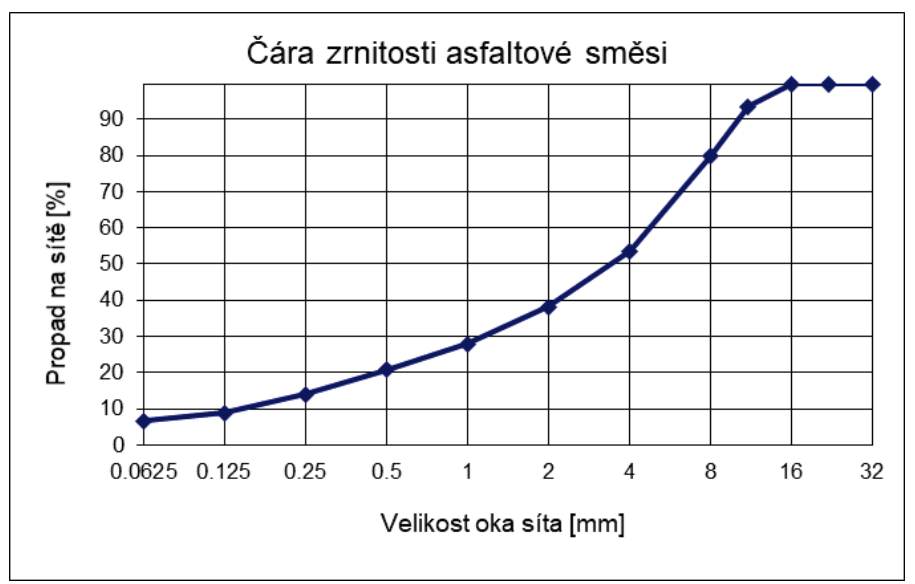

Obr. 1 Č́ra zrnitosti. 


\section{VÝSLEDKY}

\section{Bod lámavosti}

Bod lámavosti byl vyhodnocen poté, co dvojice po sobě provedených měření splňovala rozdíl teplot $\pm 3{ }^{\circ} \mathrm{C}$. $\mathrm{Z}$ těchto dvou měření byl poté aritmetickým průměrem určen bod lámavosti. Pro získání platných měření byly u většiny testovaných asfaltů provedeny 2 až 3 dvojice měření.

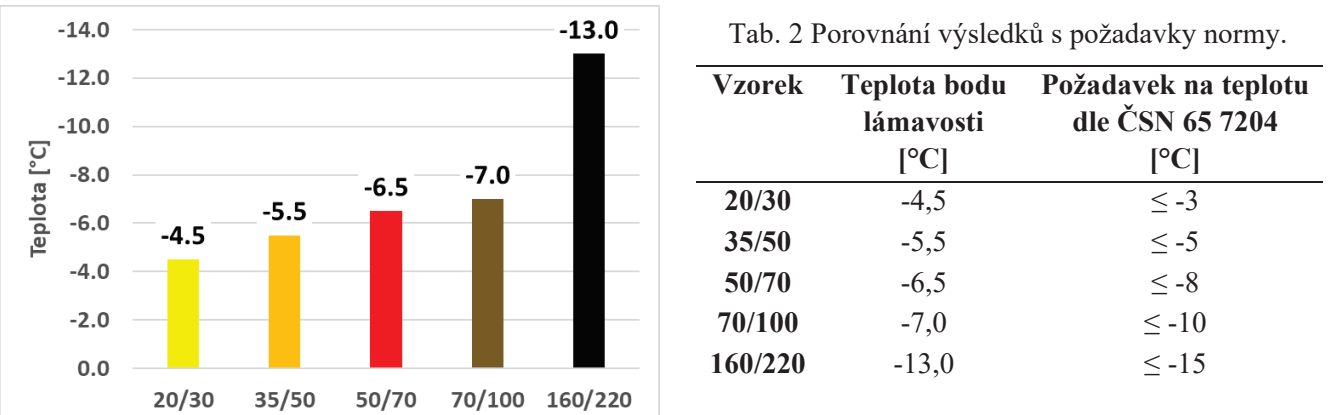

Obr. 2 Bod lámavosti metodou dle Fraasse.

Na Obr. 2 je vidět, že teplota bodu lámavosti s přibývající hodnotou penetrace podle očekávání klesá. Avšak jak je uvedeno v Tab. 2, požadavky pro hodnoty bodu lámavosti dle ČSN 657204 splňují pouze nejtvrdší zkoušená pojiva třídy $20 / 30$ a $35 / 50$.

\section{Modul tuhosti za ohybu}

Druhou prováděnou zkouškou bylo určení modulu tuhosti za ohybu pomocí průhybového trámečkového reometru. Kritická teplota byla určena pomocí m-hodnoty, a to při m-hodnotě rovnající se 0,3 . Druhým způsobem určení kritické teploty bylo pomocí modulu tuhosti za ohybu, kdy za kritickou teplotu je považována teplota při modulu tuhosti $300 \mathrm{MPa}$.

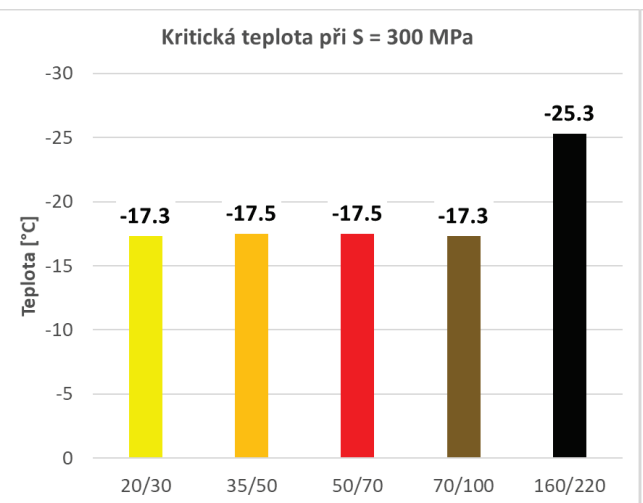

Obr. 3 Kritická teplota pojiv při $\mathrm{S}=300 \mathrm{MPa}$.

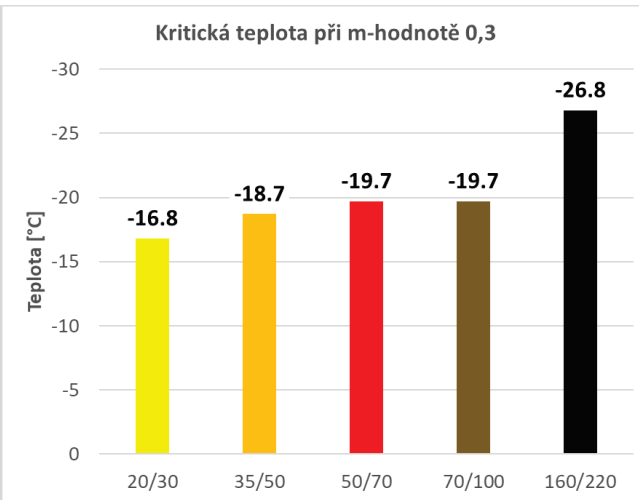

Obr. 4 Kritická teplota pojiv při m-hodnotě 0,3 .

Z Obr. 3 je zřetelné, že nízkoteplotní vlastnosti měřených pojiv jsou ve velmi podobných hodnotách, s výjimkou nejměkčího pojiva třídy 160/220, které podle očekávání svojí hodnotou kritické teploty značně převyšuje ostatní. Především pojivo 70/100 se liší od očekávaných výsledků, kdy se zvyšující se penetrací je očekáváno snížení kritické teploty.

Výsledné kritické teploty dle m-hodnoty dle Obr. 4 lépe popisují chování pojiv a s jejich stoupající penetrací se snižuje výsledná kritická teplota. 


\section{Kritická teplota směsi dle testu TSRST}

Zkouškou nízkoteplotních vlastností asfaltových směsí pomocí TSRST je vyhodnocena kritická teplota při porušení společně s maximálním tahovým napětím, při kterém došlo k porušení vzorku. Výsledná kritická teplota byla vyhodnocena jako průměr dvou měření, avšak u tělesa s pojivem frakce 160/220 byla kritická teplota natolik nízká, že došlo k porušení pouze u jednoho tělesa. Výsledné hodnoty jsou znázorněny v Obr. 5 a Obr. 6.
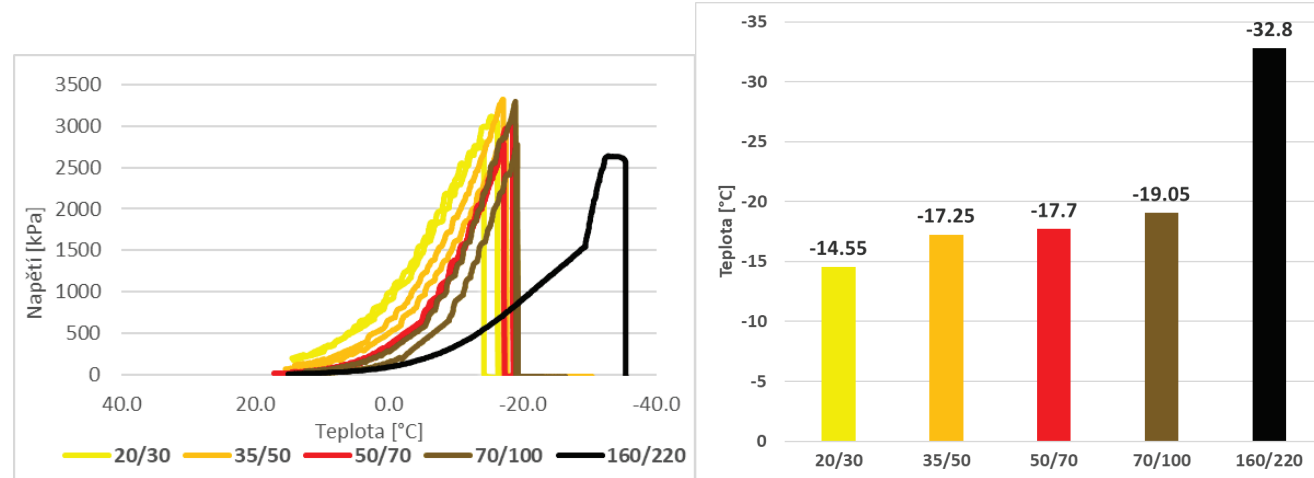

Obr. 5 Průběh napětí v asfaltové směsi při zkoušce TSRST.

Obr. 6 Kritická teplota směsi dle testu TSRST.

Průběh napětí a výsledná kritická teplota testovaného tělesa je opět závislá na třídě použitého pojiva. Se zvyšující se penetrací pojiva je nárůst napětí pomalejší a kritická teplota se tedy pohybuje v nižších hodnotách.

\section{Korelace výsledků prováděných zkoušek}

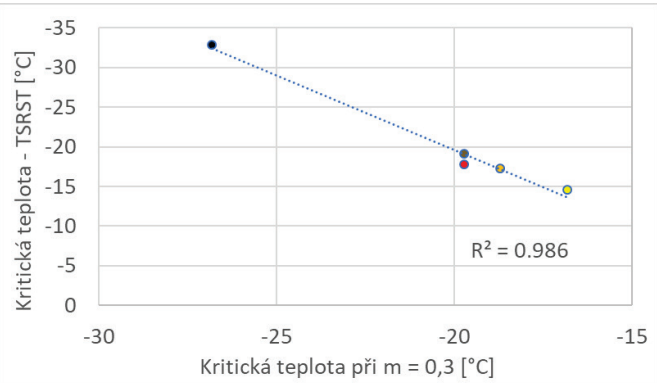

Obr. 7 Korelace výsledků zkoušky TSRST a - hodnoty ze zkoušky BBR.

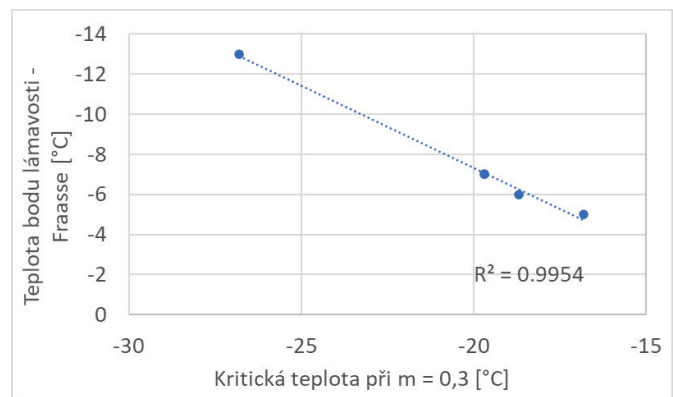

Obr. 9 Korelace výsledků zkoušky Fraasse a -hodnoty ze zkoušky BBR.

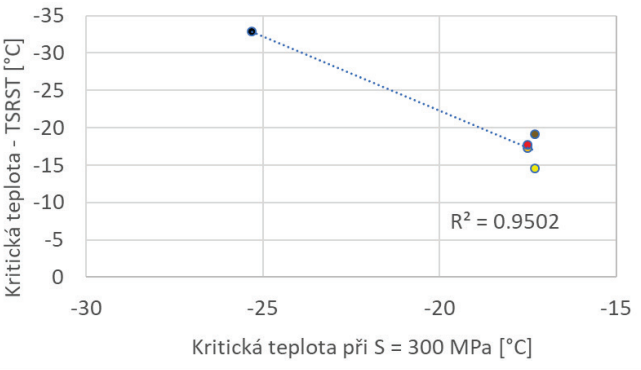

Obr. 8 Korelace výsledků zkoušky TSRST a modulu tuhosti za ohybu S ze zkoušky BBR.

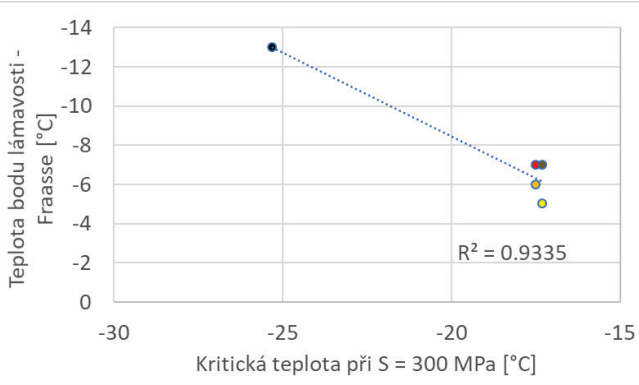

Obr. 10 Korelace výsledků zkoušky Fraasse a odulu tuhosti za ohybu S ze zkoušky BBR. 


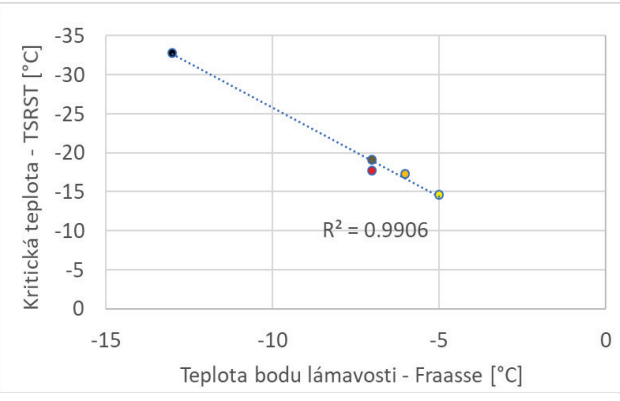

Obr. 11 Korelace výsledků zkoušky Fraasse a TSRST.
Tab. 3 Korelační matice.

\begin{tabular}{c|c|c|c}
\hline $\begin{array}{c}\text { Koeficient } \\
\text { determinace }\end{array}$ & $\begin{array}{c}\text { Kritická teplota } \\
\text { (TSRST) }\end{array}$ & m-hodnota & Fraasse \\
\hline $\begin{array}{c}\text { Krit. teplota } \\
\text { (TSRST) }\end{array}$ & $\mathrm{X}$ & $\mathrm{X}$ & $\mathrm{X}$ \\
\hline m-hodnota & 0,986 & $\mathrm{X}$ & \\
\hline Fraasse & 0,991 & 0,955 & $\mathrm{X}$ \\
\hline $\begin{array}{c}\text { Modul tuhosti } \\
\text { za ohybu S }\end{array}$ & 0,950 & $\mathrm{X}$ & 0,934 \\
\end{tabular}

Všechny koeficienty determinace, které jsou znázorněny v Obr. 7, Obr. 8, Obr. 9, Obr. 10, Obr. 11 a Tab. 3, byly vyhodnoceny proložením hodnot lineární křivkou. Korelace mezi $\mathrm{m}$-hodnotou a modulem tuhosti $\mathrm{S}$ nebyla provedena, nebot' se jedná o dva různé výsledky ze stejné zkoušky.

\section{ZÁVĚR}

Z provedených zkoušek je znatelné, že korelace mezi zkouškami je velmi vysoká. Zkouška určení bodu lámavosti dle Fraasse vykazovala nízkou opakovatelnost, kdy z každé třídy pojiva bylo potřeba otestovat nejméně tři sady vzorků. U provedené zkoušky TSRST bylo problémem stanovení kritické teploty u těles s použitým pojivem třídy 160/220, které byly natolik plastické, že nedošlo k jejich porušení a zkouška musela být provedena na větším počtu těles.

Nejvyšší hodnota koeficientu determinace byla dosažena při porovnání zkoušky bodu lámavosti dle Fraasse se zkouškou určení kritické teploty pomocí TSRST, a to 0,991. Hodnota zbývajících koeficientů determinace při porovnání výsledků zkoušky určení kritické teploty pomocí TSRST s výsledky zkoušky pomocí průhybového trámečkového reometru vycházeli $\mathrm{v}$ hodnotách 0,986 při porovnání $\mathrm{s}$ kritickou teplotou při m-hodnotě 0,3 a zároveň 0,950 při porovnání s kritickou teplotou při modulu tuhosti za ohybu $300 \mathrm{MPa}$.

U zkoušky asfaltových pojiv v průhybovém trámečkovém reometru byl závěrem fakt, že kritická teplota získaná z m-hodnoty, umí lépe popsat rozdíly mezi chováním jednotlivých srovnávaných pojiv než kritická teplota, stanovená na základě modulu tuhosti za ohybu. Avšak výsledné hodnoty modulu tuhosti za ohybu i m-hodnot byly, krom asfaltu s nejvyšší penetrací, v relativně stejných hodnotách a nereprezentovaly skutečné chování materiálu.

\section{Použité zdroje}

[1] IPCC, 2021: Climate Change 2021: The Physical Science Basis. Contribution of Working Group I to the Sixth Assessment Report of the Intergovernmental Panel on Climate Change [Masson-Delmotte, V., P. Zhai, A. Pirani, S.L. Connors, C. Péan, S. Berger, N. Caud, Y. Chen, L. Goldfarb, M.I. Gomis, M. Huang, K. Leitzell, E. Lonnoy, J.B.R. Matthews, T.K. Maycock, T. Waterfield, O. Yelekçi, R. Yu, and B. Zhou (eds.)]. Cambridge University Press. In Press.

[2] Bc. Petr Veselý Nízkoteplotní vlastnosti asfaltových pojiv a směsí. Brno, 2021. 80 s., 9 s. př́l. Diplomová práce. Vysoké učení technické v Brně, Fakulta stavební, Ústav pozemních komunikací. Vedoucí práce Ing. Ondřej Dašek, Ph.D.

[3] NOWAK, Tomáš. HODNOCENÍ STAVU POZEMNÍCH KOMUNIKACÍ V ČR. Brno, 2012. Ba.

[4] ČSN EN 12593. Asfalty a asfaltová pojiva - Stanovení bodu lámavosti podle Fraasse. Praha: Český normalizační institut, 2015.

[5] ČSN EN 14771. Asfalty a asfaltová pojiva - Stanovení modulu tuhosti za ohybu pomocí průhybového trámečkového reometru (BBR). Praha: Český normalizační institut, 2012.

[6] ČSN EN 12697-46 Asfaltové směsi - Zkušební metody - Část 46: Nízkoteplotní vlastnosti a tvorba trhlin pomocí jednoosé zkoušky tahem. Praha: Český normalizační institut, 2021. 